\title{
Concrete-encased CFST structures: behaviour and application
}

\author{
L. H. Han ${ }^{a *}$, D. Y. Ma ${ }^{a}$ and K. Zhou ${ }^{a}$

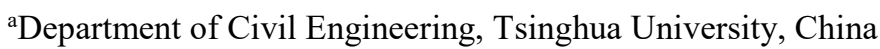 \\ *corresponding author, e-mail address: 1hhan@mail.tsinghua.edu.cn
}

\begin{abstract}
Concrete-encased CFST (concrete-filled steel tube) is a kind of composite structure comprised of a CFST component and a reinforced concrete (RC) component. The concrete encased CFST possesses superior ductility and higher stiffness. They are gaining popularity in high-rise buildings, large-span structures, bridges, subway stations and workshops. This paper initially reviews the recent research on concrete-encased CFST structures. The major research findings on bond performance, static performance, dynamic performance and fire resistance are presented. This paper also outlines some construction considerations, such as the utilization of materials, the fabrication of the steel tube, and the methods of casting the inner and outer concrete. Finally, some typical practical projects utilizing concrete-encased CFST members are presented and reviewed.
\end{abstract}

Keywords: concrete-encased; concrete-filled steel tube (CFST); structural behaviour; composite action; construction.

\section{Introduction}

Concrete-encased CFST (concrete-filled steel tubes) are a kind of composite member consisting of an inner CFST component and an outer reinforce concrete (RC) component as an encasement. These kinds of composite members are characterized by high earthquake resistance, superior ductility, high compressive strength, high shear strength and ease of construction. Five typical concrete-encased CFST sections popularly used in China are presented in Fig. 1. Steel tubes with different sections, such as circular section (CS), square section (SS) and rectangular section (RS), are used. They are usually aligned centrally with

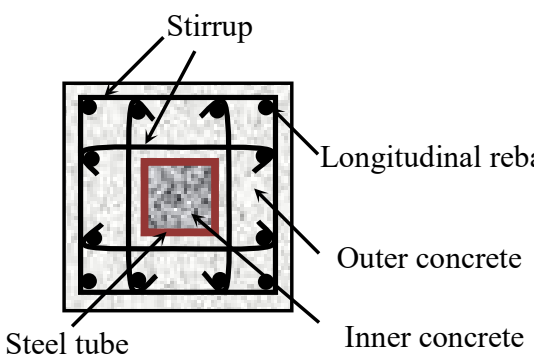

(a)

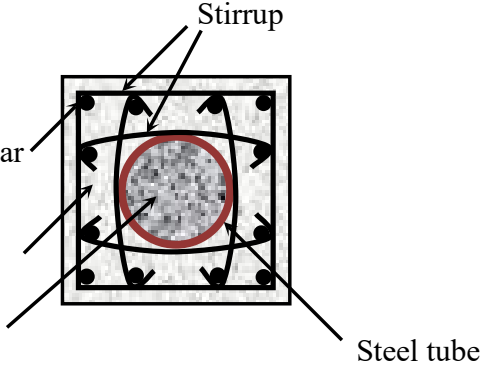

(b) respect to the outer $\mathrm{RC}$ component. This kind of composite member was initially designed to achieve a good seismic performance by applying a greater load ratio on the inner CFST component and a lesser load ratio on the outer $\mathrm{RC}$ component, so that the outer $\mathrm{RC}$ component has high capacity of resisting compression when subjected to seismic action. It was first used in China in 1995 to improve steel reinforced concrete (SRC) structures. The idea of applying RC encasement to the outer is similar to SRC, which has also been also illustrated in Eurocode [1]. 


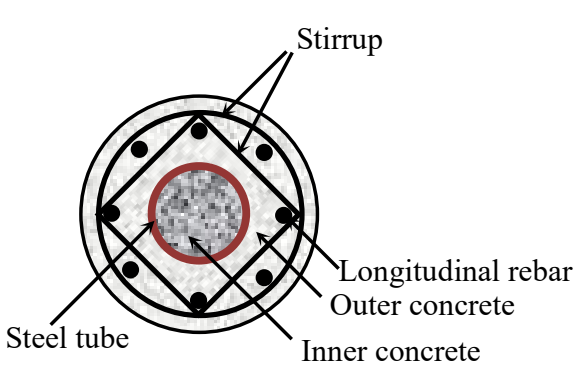

(d)

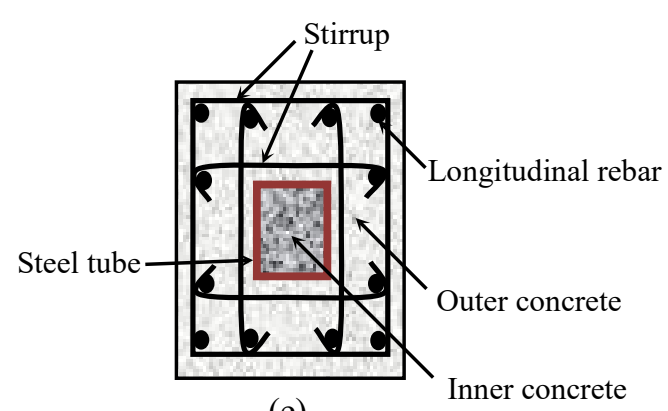

(e)

Fig. 1. Typical sections of the concrete-encased CFST.

Concrete-encased CFST also has some benefits in respect to construction. The inner steel tube is usually erected first, and it can serve as the support for the following construction. The concrete filled in the steel tube can be cast before the outer concrete or together with the outer concrete. The former and the latter methods are defined as the different-stage construction and the same-stage construction, respectively. Another benefit is that concrete-encased CFST column can be easily connected to RC beams. The configurations of the joint can be implemented based on the RC beam to RC column joints.

\section{Behaviour of concrete-encased CFST members}

Concrete-encased CFST structures can generally be classified by their structural functions: members, connections/joints and structural systems. The behaviour of each category has been studied in the past decade. The research purposes are to provide design recommendations, to promote practical applications and to lead to code coverage. Existing research on the performance of concrete-encased CFST structures is presented below, including bond performance, confinement effects, static performance, dynamic performance and fire performance.

\subsection{Bond performance}

Effective stress transfer between the steel tube and the outer concrete are required to ensure the composite action of the CFST component and the RC component. A series of tests have been carried out to investigate the bond performance of concrete-encased CFST columns by Han et al. [2]. The measured bond stress versus slip relationships of a CFST column with circular section [3] and a concrete- encased CFST column with circular steel hollow section [2] are compared in Fig. 2. It can be found that the bond strength of the concreteencased CFST column is approximately triple that of the CFST column. It indicates that the composite action of the inner CFST component and the outer $\mathrm{RC}$ component can be well achieved without using additional shear connectors. Meanwhile, it is interesting to find that the bond stress versus slip relationships of the concrete-encased CFST column fluctuates dramatically, while that of the CFST column is smooth. To the authors' best knowledge, no publication is available on the bond performance of concrete-encased CFST column after fire. But the bond performance of CFST column after fire has been experimentally studied by Tao et al. [3], and the key influencing parameters were identified.

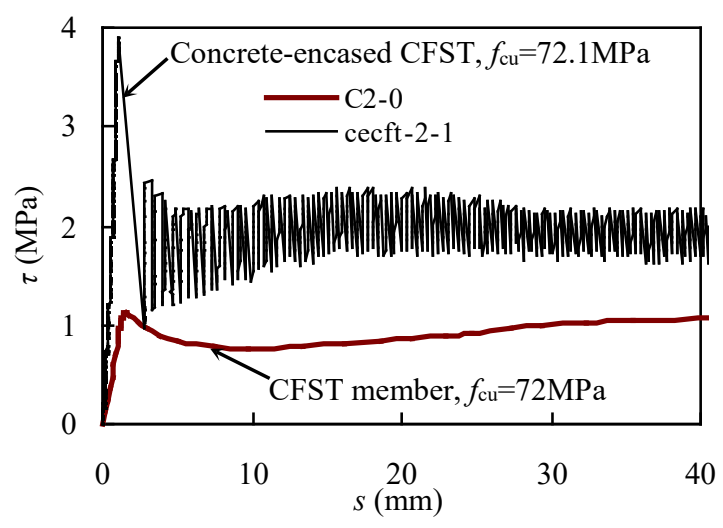

Fig. 2. Bond stress $(\tau)$ versus slip $(s)$ relationships [2].

\subsection{Confinement effects between the steel tube and the concrete}

The confinement effects come from the structural interaction between the steel tube and the concrete. The confinement effects can improve the structural behaviour of the concrete-encased CFST structures. 
The confinement effect between the steel and concrete components in CFST has been studied by many researchers [4]. It is believed that the confinement effect is related to the cross-sectional profile as well as the material properties. The confinement of concreteencased CFST is not only between the steel tube and inner concrete, but also between the steel tube and outer concrete. The outer concrete can provide confinements to the steel tube, which can prevent the steel tube from early local buckling [5]. Moreover, the CFST component can sustain the load after the crushing of outer concrete, which is beneficial for the ductility of concrete-encased CFST members [6].

\subsection{Static performance}

The static performance includes the behaviour of concrete-encased CFST members

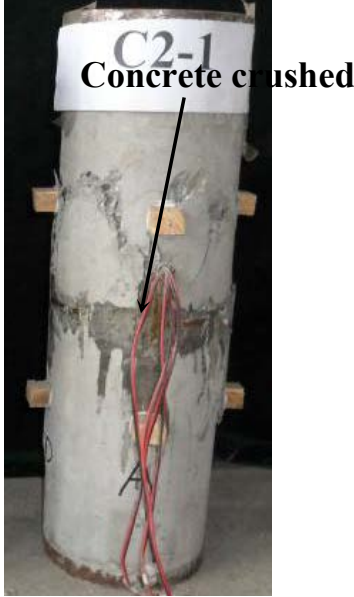

(a)

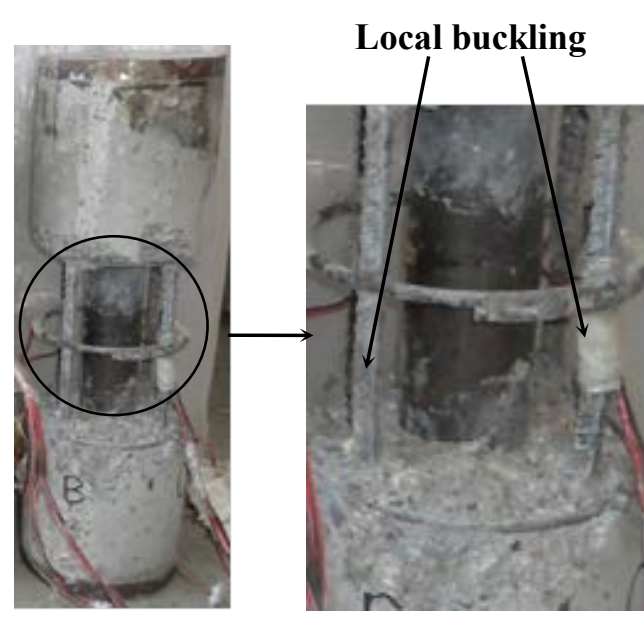

(b) under axial compression, axial tension, bending moment and eccentric loading. The existing experimental research of concrete-encased CFST stub column under axial compression load includes concrete-encased CFST columns with circular section (Fig. 1(d)) [7], square section (Fig. 1(b)) [5][8]. As reported by researchers, the failure modes of concreteencased CFST stub columns are usually characterized by the mid-height crushing of outer concrete, as shown in Fig. 3(a). Furthermore, significant local buckling at midheight longitudinal rebars can be observed as show in Fig. 3(b). By contrast, the steel tube kept intact after the test. In addition, due to the effective confinement of the steel tube, the concrete core is not crushed as shown in Fig. 3(c). It indicates that the inner CFST component becomes the main part supporting the load after the outer concrete crushes.

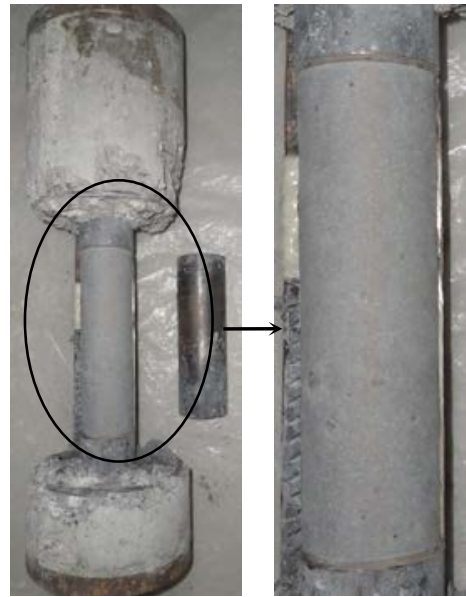

(c)

Fig. 3. Failure modes of typical concrete-encased CFST stub columns.

The axial compressive behaviour has also been investigated. Fig. 4 shows the measured load $(N)$ versus axial deformation ( $\Delta)$ relationships of a concrete-encased CFST stub column as well as that of its RC counterpart. The RC counterpart rc1-1 and rc1-2 have identical test parameters. It can be found that the load carrying capacity of the concreteencased CFST stub column is $40.4 \%$ higher than that of its RC counterpart. Meanwhile, compared to its RC counterpart, the descent stage of $\mathrm{N}-\Delta$ relationships of the concreteencased CFST stub column is smoother. The deformation corresponding to the peak load is improved by $25.97 \%$. This indicates that the concrete-encased CFST stub column possesses superior axial compressive strength and ductility than the RC stub column.
Theoretical studies on the concrete-encased CFST stub column under axial compressive loading are also available [4][5]. It can be found that the compressive strength of the concreteencased CFST stub column is higher than the simple superposition of the compressive strength of each part, i.e., the longitudinal reinforcement, the outer concrete, the inner concrete and the steel tube. 


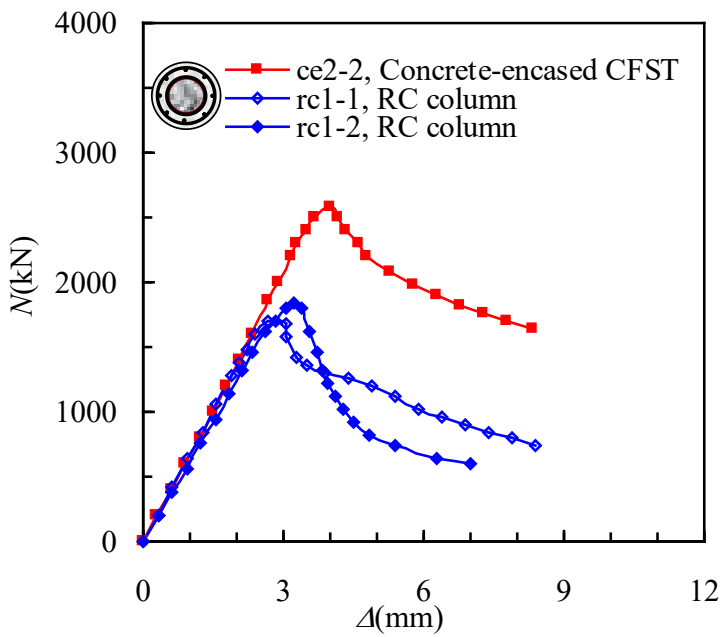

Fig. 4. Load $(N)$ versus axial deformation $(\Delta)$ relationships of stub columns [7].

The bending behaviour of concrete-encased CFST beams with square section (Fig. 1(b)) was investigated by An et al. [9]. Three methods were used, i.e., experimental method, ultimate balance method and strap method. It should be noted that the steel tube has limited influence on the bending strength of concreteencased CFST beams. The behaviour of concrete-encased CFST columns under eccentric loading has also been investigated. Various cross sections were studied, such as circular section (Fig. 1 (d)) [4] square section (Fig. 1 (b)) [9] and rectangular section (Fig. 1(e)) [11]. The measured load $(N)$ versus axial deformation $(\Delta)$ relationships of a concreteencased CFST beam-column are presented in Fig. 5. The strain corresponding to the ultimate strength of the concrete-encased CFST column exceeds that of the outer RC component by $23.0 \%$ due to the contribution of the inner CFST component.

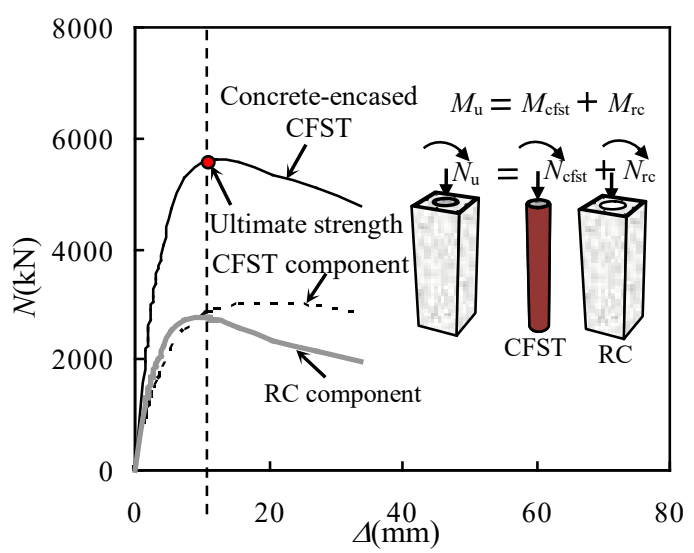

Fig. 5. Load $(N)$ versus axial deformation $(\triangle)$ relationships of beam-columns [6]

\subsection{Dynamic performance}

As stated above, concrete-encased CFST members were initially designed to achieve a good seismic performance by applying a greater load ratio on the inner CFST component and a lesser load ratio on the outer RC component, so that the outer RC component has higher capacity of developing compression when subjected to seismic action. A large number of research work is available on the dynamic performance of the concrete-encased CFST member. The studies of dynamic behaviour include cyclic behaviour and impact behaviour.

Some experimental studies have been conducted on the cyclic behaviour of concreteencased CFST beam-columns [12][13][14][15]. It can be found from these tests that concreteencased CFST beam-columns exhibit favourable energy dissipation and ductility, even when they are subjected to high axial compression loads. The analytical research has been conducted by Qian et al. [16] and Ma et al. [17]. As recommended by Qian et al. [16], the concrete-encased CFST column exhibits good ductility performance under cyclic loading, where the curvature ductility coefficient can be $15 \%$ higher than the $\mathrm{RC}$ counterpart. It confirms that concrete-encased CFST column is suitable for application in regions of high seismicity [12].

The existing concrete-encased CFST joints include the concrete-encased CFST column to RC beam joint [18][19] and the concreteencased CFST column to steel beam joint [4][19]. The test results indicate that both joints exhibit favourable energy dissipation and high shear strength. For the high shear and bending strength of a concrete-encased CFST column, the failure usually occurs at beam ends rather than at column ends or joint.

The studies on the impact behaviour of concrete-encased CFST beam-column are limited. Han et al. [20] conducted experimental studies on concrete-encased CFST beamcolumn. Compared to the RC counterpart, concrete-encased CFST beam-column exhibits an overall deformation under lateral impact. The major penetrating cracks, commonly observed in RC beam-columns, were not observed in concrete-encased CFST beamcolumn. This kind of beam-column shows ductile failure mode under lateral impact. 


\subsection{Fire performance}

Experimental investigations have been conducted on the fire performance of concreteencased CFST column. Ten tests were conducted, including six fire resistance tests and four postfire tests [21]. The specimens were subjected to a combined effect of both loading and fire, consisting of a loading phase at ambient temperature, a standard fire exposure phase, a cooling phase and postfire loading phase. The test parameters investigated were load ratio, dimension of steel tube and heating time ratio. Fig. 6 shows the failure modes of

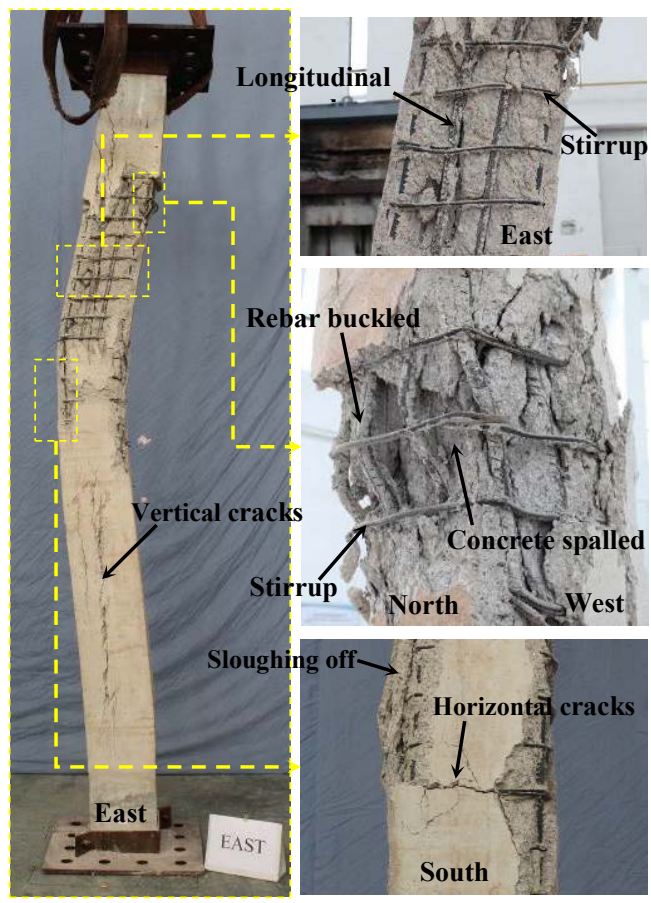

(a) Fire resistance test concrete-encased CFST after tests. The global buckling failure mode was observed for all tested specimens. Compared with fire resistance tests (Fig. 6 (a)), the failure modes of postfire tests (Fig. 6 (b)) exhibited more evident plastic hinges near mid-height and both ends. After the tests, the outer concrete was removed and the inner steel tubes were cut open at the locations where the lateral deflection peaked. The removal of outer concrete was tough, indicating that the reinforcement provided efficient confinement to the inner components after fire exposure.

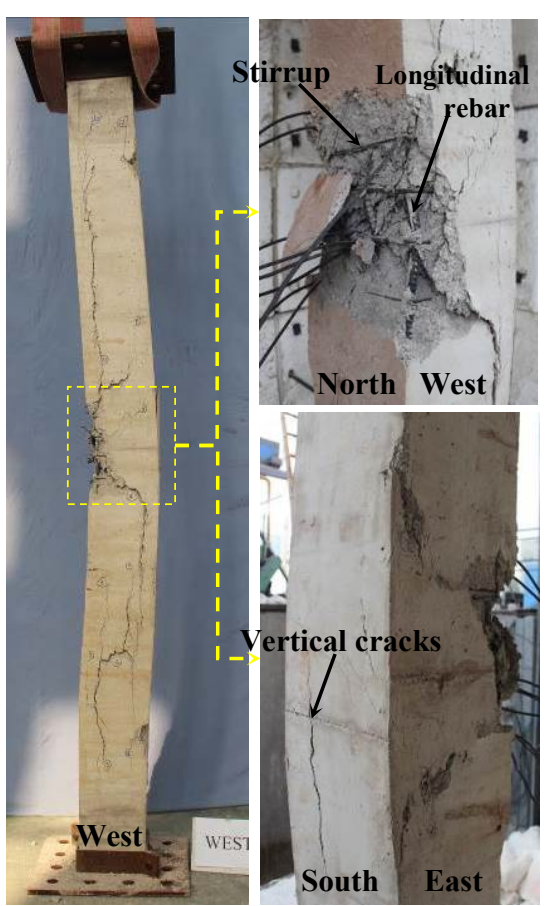

(b) Postfire test

Fig. 6. Failure modes of concrete-encased CFST column in fire tests.

Fig. 7 shows the measured furnace temperature $(T)$ versus time $(t)$ relationships of one postfire specimens. Some major findings include: (1) Plateau stage around $100^{\circ} \mathrm{C}$ of concrete near steel tube (points 2 and 3) are more obviously observed than the other parts. (2) Temperature differences are captured between the inner and outer tube surfaces. This may be related to 1) the possible movement of the measuring end and 2) the possible gap of the tube and concrete. (3) The inner crosssection attains its peak temperature much later than the outer in the postfire tests. (4) The temperature attained by inner CFST component is low due to the insulating effect provided by outer RC component. It indicated that the strength of the inner concrete was not dramatically reduced.

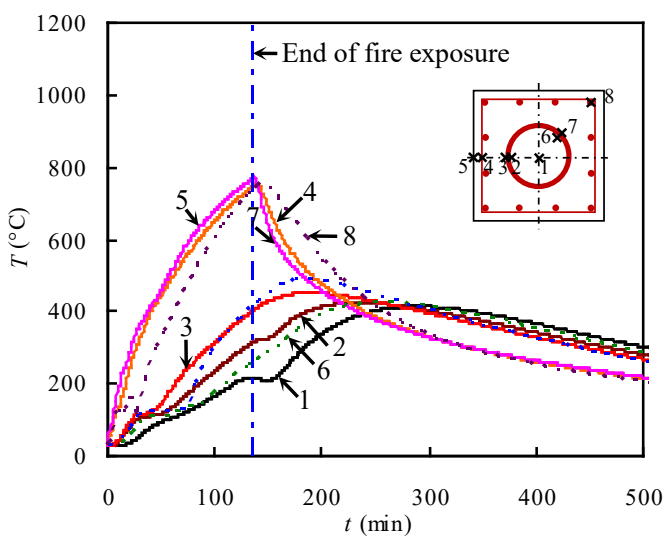

Fig. 7. Measured specimen temperature $(T)$ versus time $(t)$ relationships[21]. 


\section{Construction considerations}

\subsection{Fabrication of the steel tube}

For the straight seam welded steel tube and the spirally welded steel tube, the steel tube is made from the steel plate. For the seamless steel tube, the steel tube is made from a solid round steel billet. The manufacturing process of steel tubes differs with the manufacturing method. The assembly of joints should be conducted in professional steel factory. The inner surface of the steel tube shall be derusted before welding. The openings on the steel tube should be sealed before transport to keep the inside clean.

\subsection{Casting of the concrete}

Good performance shall be guaranteed for the inner concrete, such as high strength, high stiffness, low shrinkage, low creep, good workability, and no segregation or corrosion. For the concrete with strength greater than $60 \mathrm{MPa}$, the mix proportion design should be trialled before construction. Before casting the concrete, a clean inner surface shall also be guaranteed.

The quality of concrete filling shall be checked after casting. One practical method is hitting the tube with a hammer from the outside. The defect in concrete would make different sounds at the tube over it. If any abnormity is detected, ultrasonic detection can be further used. The defects can be fixed by opening a hole on the tube, injecting high strength cement and closing the openings.

The outer RC component is constructed

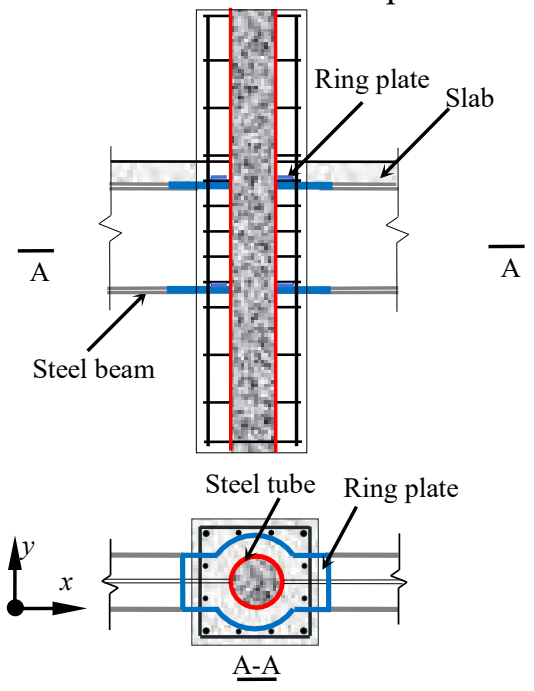

(a) Ring plate to steel beam joint

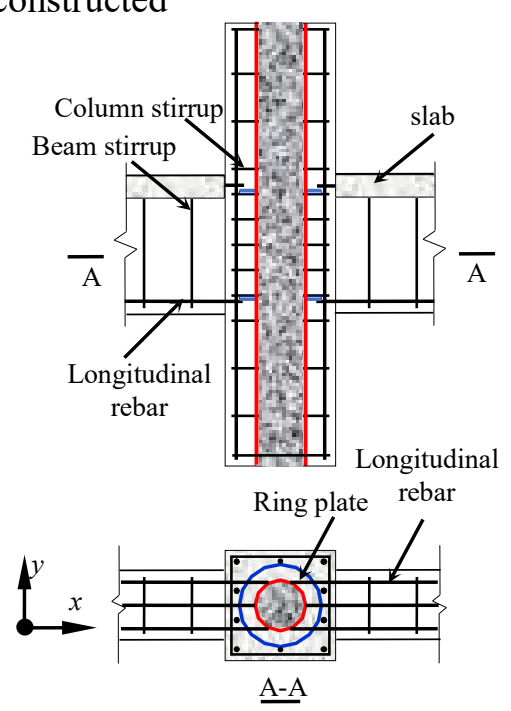

(b) Ring plate to $\mathrm{RC}$ beam joint differently according to the construction methods. For the different-stage construction, the reinforcing cage is erected after the inner CFST component is finished. For the samestage construction, the inner concrete and outer concrete are cast simultaneously after the reinforcing cage is erected. The reinforcing cage shall be derusted before placement. The self-consolidation concrete (SCC) and normal concrete are recommended for the $\mathrm{RC}$ component.

\subsection{Construction of beam-column joints}

The beam-column joint is crucial to the whole structural system. The concept of 'strong-joint and weak-member' shall be achieved in practical design. To ensure the continuity of the concrete-encased CFST columns, both the steel tube and the rebars in the column shall penetrate the joint area.

The concrete-encased CFST columns are usually connected to steel beam and RC beam. For the first kind of joint, the I-shaped steel beam can be connected to the steel tube by ring plates as shown in Fig. 8(a). The ring plates are prefabricated with the steel tube, and the steel beam can be connected in situ. For the second kind of joint, the longitudinal rebars in the $\mathrm{RC}$ beam are connected to the steel tube via ring plates or sleeves as shown in Fig. 8(b)(c). The ring plates and sleeves are also prefabricated. The ring plates can be connected to the rebars from both $x$ and $y$ directions shown in Fig. 8 . The sleeve has advantage for the exterior joints and the staggered joints.

Fig. 8. The connection of concrete-encased CFST column joints. 
To ensure a proper welding thickness, the thickness of the ring plate should be greater than the wall thickness of steel tube, the flange thickness of steel beam or the radius of rebars. For the sleeve connection, the anchorage length should be greater than the diameter of the rebar to ensure the enough anchorage force. To allow for proper casting room, the distance between adjacent sleeves should be greater than $25 \mathrm{~mm}$ as well as the diameter of steel rebar.

\section{Applications of concrete-encased CFST members}

Concrete-encased CFST members have been used in China for more than two decades. They are gaining popularity in recent years in China due to the improvement of theory and technology. Concrete-encased CFST members have been used in buildings, bridges and other infrastructures in recent years. Some typical examples of these composite structures are presented below.

\subsection{Buildings}

The application history of concrete-encased CFST members in buildings can be divided into two stages: the initial stage and the later stage. In the initial stage (late 1990s), the concreteencased CFST members are mainly used in the high-rise buildings in Shenyang due to the high requirement of earthquake resistance. In the later stage, the applications of concrete-encased CFST members spread to other cities of China.

Some examples of the initial stage are the Postal Terminal Building of Liaoning Province (96.6m in height, the first high-rise building using concrete-encased CFST columns in China, finished in 1996), Hetai Building, Local Taxation Bureau Building of Heping District, Electricity Garden, Fangyuan Building, Fulin Building, the Apartment of Liaoning Tourist Office and the Building of Liaoning Book's Publication. All these buildings are located in Shenyang, China.

From the twenty-first century, this kind of composite column has been accepted by more engineers. They were used in other provinces of
China. Some examples include ZhuoyueHuanggang Century Centre in Shenzhen, Huarun-Junyue Hotel in Shenzhen, Baoli Square in Shanghai, Tiancheng Building in Chongqing, Straits Exchange Centre Phase 2 in Xiamen and Changfu-Jinmao Tower in Shenzhen. Take Zhuoyue-Huanggang Century Centre as an example, the total height of the building is $280 \mathrm{~m}$, and 22 concrete-encased CFST columns are used around the RC core tube. The dimension of the outer cross section and the diameter of the inner circular CFST are $1400 \mathrm{~mm}$ and $1060 \mathrm{~mm}$, respectively. Concrete-encased CFST columns are also suitable in large-span buildings. It has been used as main supporting system in a large exhibition, the Urban and Rural Planning Exhibition of Guiyang in Guizhou Province.

\subsection{Bridges}

The applications of concrete-encased CFST members have also been extended to bridges in China since the twenty-first century. Concreteencased CFST members have been used in arch bridge as arch ribs. Fig. 9(a) shows the Zhaohua Jialing River Bridge in Sichuan Province, China. The arch ring consists of two parallel arch ribs, and the arch length is $350 \mathrm{~m}$. Six hollow steel tubes for each arch were established first. Then they were filled with concrete in order to resist the construction load. RC component was attached outside the CFST members to form the double-cell concrete-encased CFST box section.

In addition, concrete-encased CFST members have been used in rigid frame bridge as piers. Fig. 9(b) shows a photo of the Labajin Bridge on Longxi Express. One-cell concreteencased CFST members with box section are used as piers in this bridge, whose highest pier is 182.5 meters. The steel tube is $1320 \mathrm{~mm}$ in diameter, and it is filled with high strength concrete. Fig. 10 presents two photos of the Heishigou Bridge during and after construction. This bridge is located in Sichuan Province and its piers are one-cell concrete-encased CFST with box sections. 


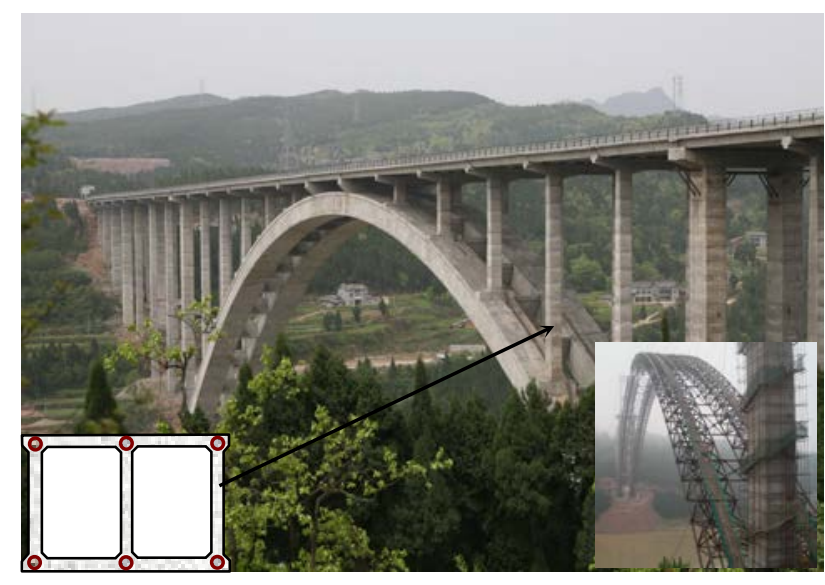

(a) Zhaohua Jialing River Bridge

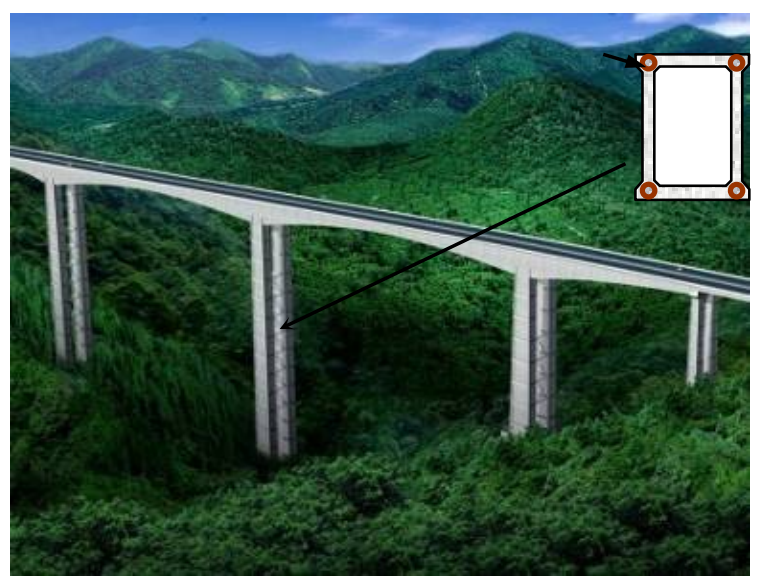

(b) Labajin Bridge

Fig. 9. Concrete-encased CFST bridges [10].

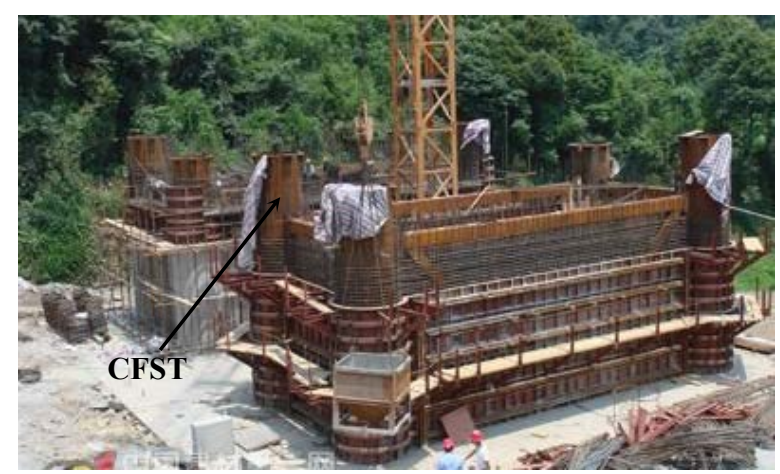

(a) During construction

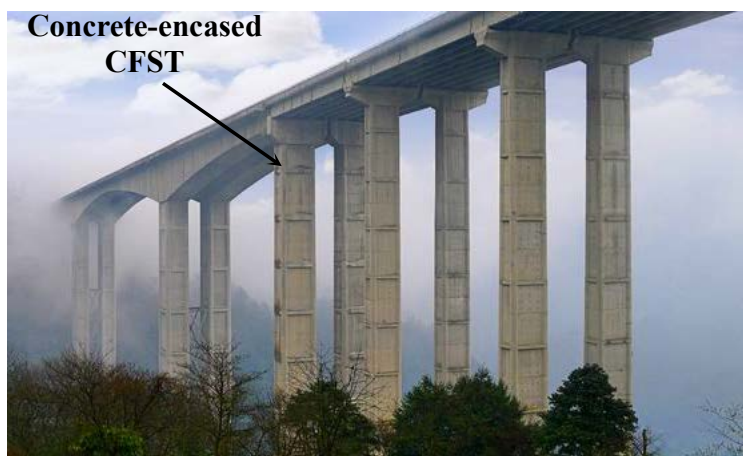

(b) After construction

Fig. 10. Heishigou Bridge in Sichuan Province [10]

\subsection{Other infrastructures}

Concrete-encased CFST members have also been used in subway stations and workshops. Since the columns in subway stations are usually subjected to high axial compression and dynamic horizontal load, the concrete-encased CFST column is suitable to be served as supporting columns in these stations. For example, Laojie Station of Line 3 of Shenzhen Metro consists of four stories underground and sixteen floors above the ground. Concrete-

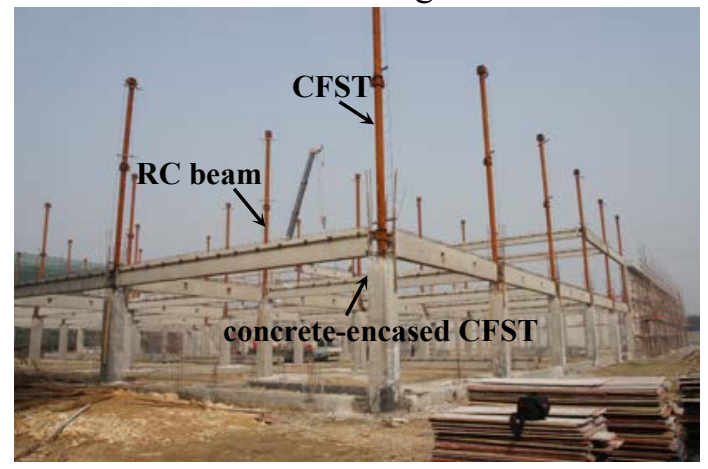

(a) Concrete-encased CFST column to RC beam encased CFST columns were adopted as the main supporting columns in the underground four stories.

In addition, concrete-encased CFST members have been used in industrial buildings in China. Fig. 11 shows two examples designed by the Huahui Design Group [19]. In these workshops, the concrete-encased CFST columns were easily connected to steel beams or RC beams.

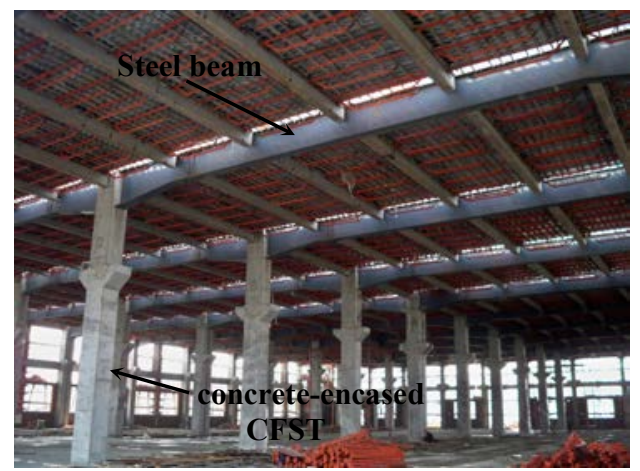

(b) Concrete-encased CFST column to steel beam

Fig. 11. Concrete-encased CFST in workshops [19]. 


\section{Concluding remarks}

The research and applications of concreteencased CFST structures have developed rapidly over the past two decades. The scope of concrete-encased CFST structures has been extended greatly by researchers and engineers. This paper initially reviews the research on the structural performance of concrete-encased CFST members. Some design methods and construction considerations are introduced. Finally, the application history and typical projects using concrete-encased CFST columns

\section{Acknowledgments}

The research reported in this paper is part of the Project 51678341 supported by the National Natural Science Foundation of China (NSFC). The financial support is highly appreciated.

\section{References}

[1]CEN. Design of composite steel and concrete structures, Eurocode 4, Brussels, Belgium; 2004.

[2]Han LH, Wang ZB, Xu W, Tao Z. Behavior of Concrete-Encased CFST Members under Axial Tension [J]. Journal of Structural Engineering 2016;142(2).

[3]Tao Z, Han LH, Uy B, Chen X. Post-fire bond between steel tube and concrete in concretefilled steel tubular columns [J]. Journal of Constructional Steel Research 2011;67(3):360378.

[4]Han LH, Li W, Tao Z, Wang WD. Advanced composite and mixed structures-Testing, theory and design approach (second version) [M]. Science Press, Beijing, China; 2016 [in Chinese].

[5]Han LH, An YF. Performance of concreteencased CFST stub columns under axial compression. Journal of Constructional Steel Research 2014;93: 62-76.

[6]An YF, Han LH. Behaviour of concrete-encased CFST columns under combined compression and bending. Journal of Constructional Steel Research 2014;101:314-330.

[7]Li YJ, Han LH, Xu W, Tao Z. Circular concreteencased concrete-filled steel tube (CFST) stub columns subjected to axial compression[J]. Magazine of Concrete Research 2016;68(19): 995-1010.

[8]Huang YS, Long YL, Cai J. Ultimate strength of rectangular concrete-filled steel tubular (CFT) stub columns under axial compression. Steel and Composite Structures 2008;8(2):115-128. are presented. Concrete-encased CFST structures can be used as an alternative to SRC and CFST systems. While the research on the structural behaviour of concrete-encased CFST structures is still at an early stage. Further researches on the performance of concreteencased CFST column include creep and shrinkage behaviour, impact behaviour, fire performance, durability and construction issues. These future researches are essential to gain a better understanding of concrete-encased CFST structures and facilitate their applications.

[9]An YF, Han LH, Roeder C. Flexural performance of concrete-encased concrete-filled steel tubes. Magazine of Concrete Research 2014;66(5):249-267.

[10]Han LH, An YF, Roeder C, Ren QX. Performance of concrete-encased CFST box members under bending. Journal of Constructional Steel Research 2015;106:138153.

[11]Park HG, Lee HJ, Choi IR, Kim SB, Park SS. Concrete-filled steel tube columns encased with thin precast concrete. Journal of Structural Engineering 2015;141(12):04015056.

[12]Han LH, Liao FY, Tao Z, Hong Z. Performance of concrete filled steel tube reinforced concrete columns subjected to cyclic bending [J]. Journal of Constructional Steel Research 2009;65 (8-9): 1607-1616.

[13]Ji XD, Kang HZ, Chen XC, Qian JR. Seismic behavior and strength capacity of steel tubereinforced concrete composite columns [J]. Earthquake Engineering and Structural Dynamics 2014;43(4):487-505.

[14]Wang ZB, Han LH, Li W, Tao Z. Seismic performance of concrete-encased CFST piers: experimental study[J]. Journal of Bridge Engineering 2016;21(4): 1084-0702.

[15]Shim CS., Chung YS, Han, JH. Cyclic response of concrete-encased composite columns with low steel ratio. Proceedings of the Institution of Civil Engineers-Structures and Buildings 2008;161(2):77-89.

[16]Qian WW, Li W, Han LH, Zhao XL. Analytical behavior of concrete-encased CFST columns under cyclic lateral loading. Journal of Constructional Steel Research 2016;120:206220.

[17]Ma DY, Han LH, Li W, Zhao XL. Seismic Performance of Concrete-Encased CFST Piers: Analysis [J]. Journal of Bridge Engineering 2017;23(1):04017119.

[18]Ma DY, Li W, Han LH, Zhao XL. Finite element analysis on concrete-encased CFST column to reinforced concrete beam joints. 8th 
conference on Steel and Aluminium structures, Honkong; 2016.

[19]Liao FY, Han LH, Tao Z. Behaviour of composite joints with concrete encased CFST columns under cyclic loading: Experiments[J]. Engineering Structures 2014;59:745-764.

[20]Han $\mathrm{LH}, \mathrm{Hu} \mathrm{CM}$, Hou CC. Investigation on concrete-encased CFST members under laterally low velocity impact $[\mathrm{J}]$. 13th International Conference on Steel Space and Composite Structures, Perth; 2018.

[21]Zhou K, Han LH. Experimental behavior of concrete-encased CFST columns after exposure to fire. 4th International Conference on Protective Structures (ICPS4), Beijing; 2016. 